Jap. J. M. Sc. \& Biol., 11, 129-140, 1958

\title{
AN EPIDEMIC OF ADENOVIRUS TYPE 3 INFECTIONS AMONG SCHOOL CHILDREN IN AN ELEMENTARY SCHOOL IN TOKYO
}

\author{
Hideo FUKUMI, Fumio NISHIKAWA, HiRomichi MIZUTANI, \\ Department of Bacteriology, National Institute of Health, Tokyo \\ Yoshiro YAMAGUCHI AND JUNSHI NANBA \\ Division of Preventive Medicine, Department of Health, City of Tokyo
}

(Received: April 28th, 1958)

The first wave of the Asiatic flue (the epidemic of infections by the A/ Asia/57 type influenza virus) started at the beginning of May, 1957, and almost subsided at the end of July, 1957, in Tokyo, after the people in the majority of the area had been affected to a more or less extent. However, it was anticipated from various reasons, that the flue would recur sooner or later in the fall of the same year. At about the beginning of September, attention was called to an outbreak of a disease diagnosed as probable influenza among the school children in an elementary school in the north-eastern part of Tokyo, namely the Oji Second Elementary School, because 1) the outbreak was considered as the one that might warn the second wave of the Asiatic flue in the coming fall, and 2) there were many school children who were again affected by this epidemic though they had suffered from A/Asia/57 type infection already in the first flue wave as if the fact indicated that no firm immunity could be established against A/Asia/57 type virus infection. However, it has been made clear that this epidemic was not due to A/Asia/57 type virus infection, but infection due to adenovirus type 3 . The detailed description will be presented in the present publication.

The detailed descriptions were already made by Bell, Rowe, Engler, Parrott and Huebner (1955) about epidemics of adenovirus infections which had occurred among children in summer camps and were supposed to be due to swimming bath transmission. Swimming pools might also be incriminated as one of the major modes of transmission in the epidemic of our concern, but it was very difficult to elucidate such a fact though some efforts were made for it.

福見秀雄・西川文雄・水谷裕迪（国立予防衛生研究所細菌部）

山口与四郎・難波淳士（東京都衛生局予防部防疫課） 


\section{LABORATORY METHODS}

The methods for investigations of adenovirus infections (virus isolations and serological examinations) were already given in previous publications (Fukumi, Nishikawa, Nakamura, Watanabe, Kitayama and Fujita, 1957; Fukumi, Nishikawa, Nakamura, Watanabe, Kitayama, and Kinoshita, 1958).

Typing of the adenovirus strains isolated in the present study was carried out by means of quantitative neutralization with rabbit antisera against the known adenovirus strains Nakamura (type 1), Koito (type 3) and Mayeda (type 5) (Fukumi, Nishikawa, Nakamura, Watanabe, Kitayama, and Fujita, 1957). The antigen employed for complement fixation titration of patients' sera was prepared from cultures of the adenovirus Mayeda (type 5), while the strain No. 83 from the eye swab of the patient (H. Iwamatsu) in the present epidemic was used for neutralization titration of human sera.

For isolation of influenza viruses, throat washings were inoculated intraamniotically into 11 to 12 day-embryonated hens eggs after treatment with 2000 units/cc penicillin and $2000 \mu \mathrm{g} / \mathrm{cc}$ streptomycin.

Antibody titrations of patient sera were made by hemagglutination inhibition reaction according to the so-called pattern method, after treatment of sera with $\mathrm{RDE}$ (cholera filtrate). The strain A/Adachi/2/57 (Fukumi, Mizutani, Nishikawa, Yamamoto, Okuma, and Kuriyama, 1958) was employed for the antigen for the hemagglutination inhibition reaction against $A / A s i a / 57$ type influenza, while $A / K o j i y a / 1 / 52$ and $B /$ Hamadayama/1/55 for those of old $A$ and $B$ types of influenza respectively.

\section{Epidemiological Findings}

The Oji Second Elementary School is located in the north-eastern part of Tokyo City and at the time of the epidemic, 1261 children were attending the school. This school had been attacked by A/Asia/57 type virus in the first wave of the Asiatic influenza, and the all classes of the school had been closed for about 5 days in June, 1957.

As already mentioned above, an epidemic of influenza-like illnesses was recognized among school children in the school by us, on the 7th of September, 1957, when we were asked for to make an investigation of its etiology and epidemiology. On the same day, about 10 children were clinically examined, and then throat washings and sera were taken from them. Our examinations of these materials revealed, as will be mentioned later in this publication, that the epidemic was due to infections of adenovirus type 3 .

At the beginning of October, when the epidemic seemed to have almost subsided, questionaires were distributed to the school children to let them fill in what we needed to know about the epidemiology of the outbreak in question, for example, the onset of illness, the main symptoms that they had, their ages, sexes, whether any of their household members had the same illness etc., in order to reconstruct the epidemic as well as possible.

Fig. 1 shows the time occurrence of the infections in the Oji Second Elementary School. The black columns represent those who exhisited conjunctivitis of more or less degree besides fever and pharyngitical symptoms like sore throat, coughs, injections of throat, namely the symptoms of typical pharyngoconjuctival 
fever (Group A). The shaded columns indicate the cases showing fever and pharyngitis but no eye symptoms (Group B). The white columns indicate those showing only throat symptoms and/or conjunctivitis but no fever (Group C), with only two exceptional cases who exhibited conjunctivitis. As seen in Fig. 1, the epidemic seems to have started at the last decade of August and lasted until the end of September, having its climax on September 1 to 5 .

It is fairly certain that a large part of those showing fever and pharyngitis but no eye involvement were the cases of an atypical form of pharyngo-conjunctival fever, because the curve of the occurrence of such cases runs, as seen in Fig. 1 , fairly in parallel with that of the typical cases of pharyngoconjunctival fever,

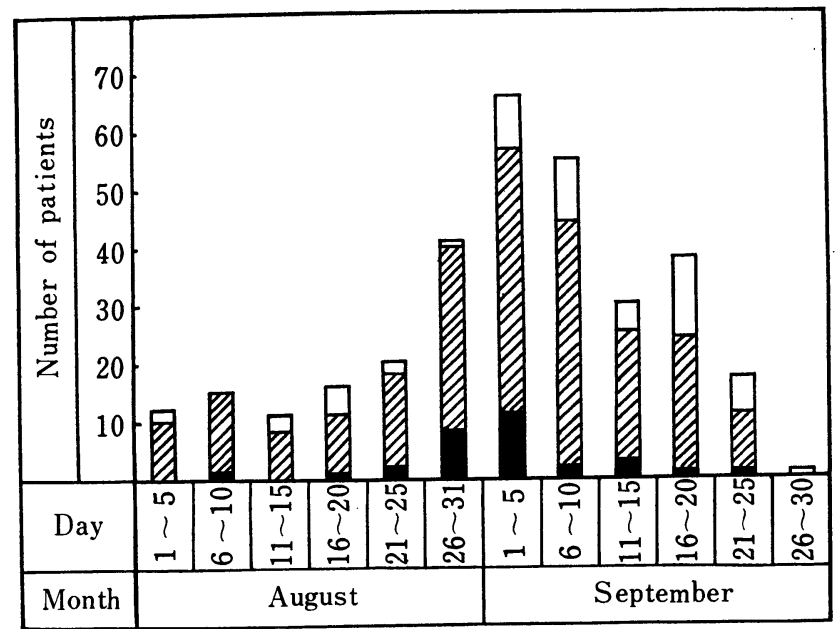

Fig. 1. Time occurrence of adenovirus infections in the Oji Second Elementary School.

$\square$ Cases with no fever. Cases with pharyngitis and fever but no conjunctivitis. Cases typical of pharyngo-conjunctival fever.

and furthermore because some of those atypical cases were, as will be mentioned later, confirmed as adenovirus infections either serologically, or by virus isolation or by the both methods. On the contrary, there may be considerable uncertainties in including those as the objects of our study those cases represented by the white columns in Fig. 1. It may, however, be acknowledged that there were two cases who showed conjunctivitis evidenced by eye discharge and conjunctival injections, and 18 cases who stated to have had conjunctival injections at the time of illness.

The class-specific infection rates are shown in Table 1, which shows that the ill children were, roughly speaking, approximately evenly distributed in each of the school classes though some minor but definite differences were observed between them. There was also no difference in the infection rate between male 
Table 1. Class-specific infection rate among the school children in the epidemic

\begin{tabular}{|c|c|c|c|c|c|c|c|}
\hline \multirow{2}{*}{ School age } & \multirow{2}{*}{ Class } & \multirow{2}{*}{$\begin{array}{l}\text { Total number } \\
\text { of children }\end{array}$} & \multicolumn{3}{|c|}{ Classification of illnesses } & \multirow{2}{*}{$\begin{array}{l}\text { Total number } \\
\text { of cases }\end{array}$} & \multirow{2}{*}{$\begin{array}{l}\text { Infection } \\
\text { rate }\end{array}$} \\
\hline & & & Group A & A Group B & Group C & & \\
\hline 1 & $\left\{\begin{array}{l}1 \\
2 \\
3 \\
4\end{array}\right.$ & $\begin{array}{l}54 \\
51 \\
55 \\
55\end{array}$ & $\begin{array}{l}1 \\
2 \\
1 \\
1\end{array}$ & $\begin{array}{r}9 \\
15 \\
10 \\
12\end{array}$ & $\begin{array}{l}5 \\
2 \\
4 \\
4\end{array}$ & $\begin{array}{l}15 \\
19 \\
15 \\
17\end{array}$ & $\begin{array}{l}28 \\
37 \\
27 \\
31\end{array}$ \\
\hline 2 & $\left\{\begin{array}{l}1 \\
2 \\
3 \\
4\end{array}\right.$ & $\begin{array}{l}60 \\
59 \\
59 \\
59\end{array}$ & $\begin{array}{l}0 \\
4 \\
0 \\
0\end{array}$ & $\begin{array}{r}9 \\
10 \\
7 \\
14\end{array}$ & $\begin{array}{l}2 \\
1 \\
6 \\
3\end{array}$ & $\begin{array}{l}11 \\
15 \\
13 \\
17\end{array}$ & $\begin{array}{l}18 \\
25 \\
22 \\
29\end{array}$ \\
\hline 3 & $\left\{\begin{array}{l}1 \\
2 \\
3 \\
4 \\
5\end{array}\right.$ & $\begin{array}{l}53 \\
53 \\
50 \\
51 \\
51\end{array}$ & $\begin{array}{l}3 \\
1 \\
1 \\
2 \\
1\end{array}$ & $\begin{array}{r}8 \\
12 \\
14 \\
15 \\
12\end{array}$ & $\begin{array}{l}1 \\
3 \\
2 \\
1 \\
4\end{array}$ & $\begin{array}{l}12 \\
16 \\
17 \\
18 \\
17\end{array}$ & $\begin{array}{l}23 \\
30 \\
34 \\
35 \\
33\end{array}$ \\
\hline 4 & $\left\{\begin{array}{l}1 \\
2 \\
3 \\
4 \\
5\end{array}\right.$ & $\begin{array}{l}51 \\
50 \\
48 \\
52 \\
48\end{array}$ & $\begin{array}{l}4 \\
0 \\
1 \\
0 \\
0\end{array}$ & $\begin{array}{r}13 \\
5 \\
7 \\
11 \\
10\end{array}$ & $\begin{array}{l}5 \\
4 \\
0 \\
2 \\
5\end{array}$ & $\begin{array}{r}22 \\
9 \\
8 \\
13 \\
15\end{array}$ & $\begin{array}{l}43 \\
18 \\
17 \\
25 \\
31\end{array}$ \\
\hline 5 & $\left\{\begin{array}{l}1 \\
2 \\
3\end{array}\right.$ & $\begin{array}{l}58 \\
58 \\
57\end{array}$ & $\begin{array}{l}3 \\
1 \\
2\end{array}$ & $\begin{array}{r}12 \\
12 \\
6\end{array}$ & $\begin{array}{l}1 \\
1 \\
5\end{array}$ & $\begin{array}{l}16 \\
14 \\
13\end{array}$ & $\begin{array}{l}28 \\
24 \\
23\end{array}$ \\
\hline 6 & $\left\{\begin{array}{l}1 \\
2 \\
3\end{array}\right.$ & $\begin{array}{l}43 \\
43 \\
43\end{array}$ & $\begin{array}{l}0 \\
0 \\
2\end{array}$ & $\begin{array}{r}10 \\
5 \\
6\end{array}$ & $\begin{array}{l}5 \\
4 \\
0\end{array}$ & $\begin{array}{r}15 \\
9 \\
8\end{array}$ & $\begin{array}{l}35 \\
21 \\
18\end{array}$ \\
\hline Total & & 1261 & 30 & 244 & 70 & 344 & 26 \\
\hline
\end{tabular}

Table 2. Sex-specific infection rates among the school children in the epidemic

\begin{tabular}{|c|c|c|c|c|c|c|}
\hline \multirow{2}{*}{ Sex } & \multirow{2}{*}{$\begin{array}{l}\text { Total number } \\
\text { of children }\end{array}$} & \multicolumn{3}{|c|}{ Classification of illnesses } & \multirow{2}{*}{$\begin{array}{l}\text { Total number } \\
\text { of cases }\end{array}$} & \multirow{2}{*}{$\begin{array}{l}\text { Infection } \\
\text { rate }\end{array}$} \\
\hline & & Group A & Group B & Group $\mathrm{C}$ & & \\
\hline Male & 631 & 13 & 124 & 34 & 171 & $26 \%$ \\
\hline Female & 630 & 17 & 120 & 36 & 173 & $27 \%$ \\
\hline Total & 1261 & 30 & 244 & 70 & 344 & $26 \%$ \\
\hline
\end{tabular}

and female children (Table 2). These data suggest fairly strongly that the transmission of the infection within class rooms either by direct contact or by some other means did not play a major role as the cause of the epidemic, though it can not be denied that a certain, not large, part of the means of the spread might be attributed to it. When we visited the school for the first time for investigation, we were told by one of the teachers in the school that a physician near the school was incriminating a swimming pool for the present epidemic of the diseases, especially the one accompanied with conjunctivitis, and calling it as swimming pool fever. There were two swimming pools (Shihongi and Nanushinotaki pools) near the school, which had been more or less used by 
the school children (Fig. 2), while some of the children of older age sometimes used another one somewhat farther from the school than the two. Among them, the Shihongi pool was said to have been the most popular for the children, because the Nanushinotaki pool was rather inconvenient to reach for a majority of the children, and a steep slope (shown in Fig. 2 as zigzag lines) might make a barrier for them to use it. Investigations were made to determine in what extent swimming baths had played a role as a mode of transmission in the present epidemic, but failed to elucidate any particular fact about it, because first, cases were reported from the both of those who had used either one or the

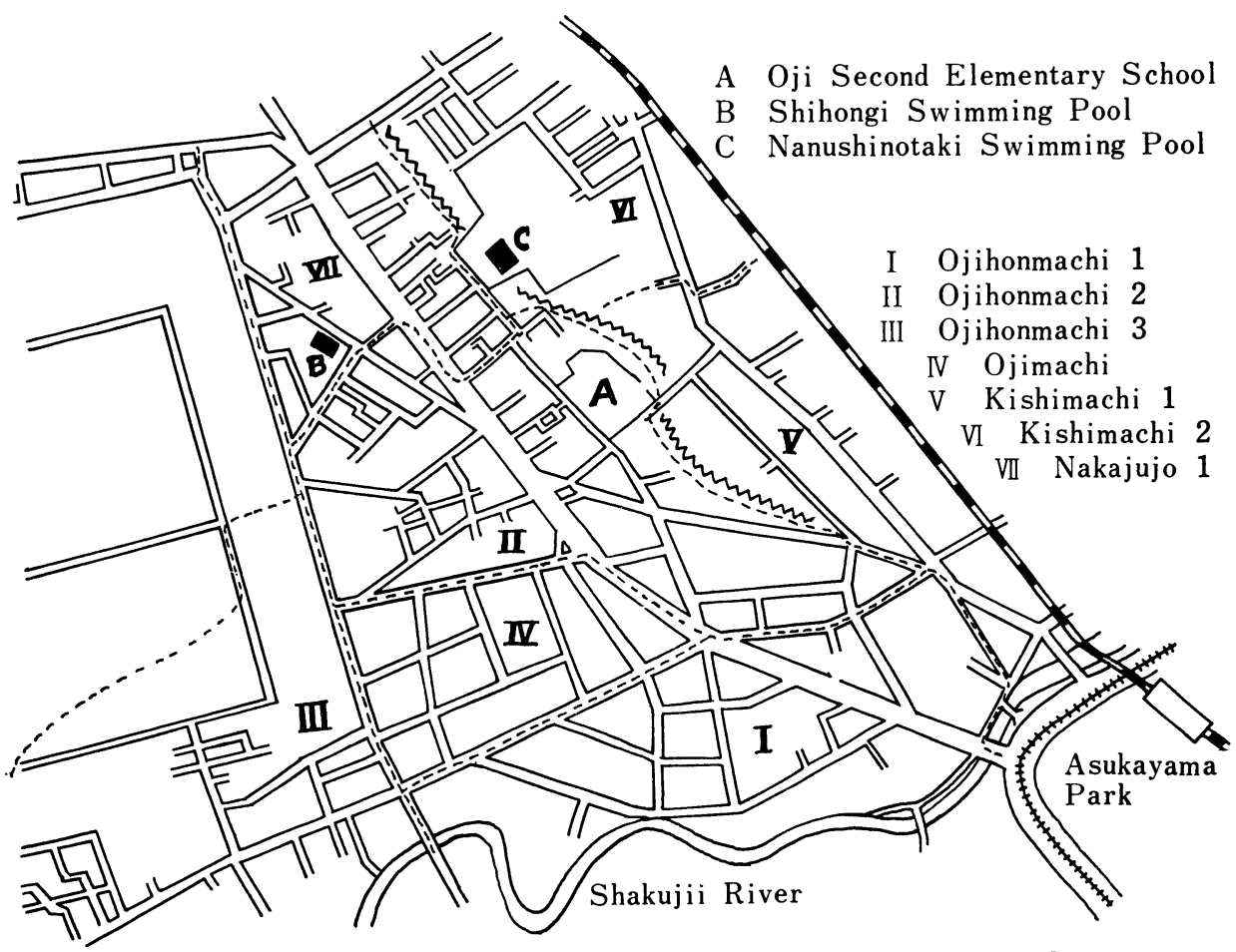

Fig. 2. The map of the area where the school children of the Oji Second Elementary School were living.

other swimming pool, and second, some of the infected children stated to have used the both swimming pools shortly before they had fallen ill.

As shown in Fig. 2, the residence area of the school children in question was divided into 7 districts, and so the district-specific infection rates were calculated from the data in filled questionaires as shown in Table 3. It is herefrom clear that the infection rates seem to be roughly equal for each district, but may be a little lower in the two districts (Kishimachi 1 and Kishimachi 2), in which it may be more convenient for the children to use Nanushinotaki pool. 
Table 3. District-specific infection rates among the school children in the epidemic

\begin{tabular}{|c|c|c|c|c|c|c|}
\hline \multirow{2}{*}{ District } & \multirow{2}{*}{$\begin{array}{l}\text { Total number } \\
\text { of children }\end{array}$} & \multicolumn{3}{|c|}{ Classification of illnesses } & \multirow{2}{*}{$\begin{array}{l}\text { Total number } \\
\text { of cases }\end{array}$} & \multirow{2}{*}{$\begin{array}{l}\text { Infection } \\
\text { rate }\end{array}$} \\
\hline & & Group A & Group B & Group C & & \\
\hline Ojihonmachi 1 & 86 & 0 & 20 & 3 & 23 & $27 \%$ \\
\hline Ojihonmachi 2 & 267 & 7 & 82 & 15 & 104 & $39 \%$ \\
\hline Ojihonmachi 3 & 155 & 5 & 35 & 11 & 51 & $33 \%$ \\
\hline Ojimachi & 178 & 8 & 27 & 21 & 56 & $31 \%$ \\
\hline Kishimachi 1 & 105 & 1 & 21 & 6 & 28 & $27 \%$ \\
\hline Kishimachi 2 & 67 & 1 & 11 & 1 & 13 & $19 \%$ \\
\hline Nakajujo & 184 & 7 & 44 & 12 & 63 & $34 \%$ \\
\hline Others & 17 & 1 & 1 & 2 & 4 & $24 \%$ \\
\hline Total & 1059 & 30 & 241 & 71 & 342 & $32 \%$ \\
\hline
\end{tabular}

After all, it is very difficult to determine the mode of transmission which played a major role in the spread of infections in the epidemic in question, though the incrimination of the swimming baths was suggested.

\section{LABORATORY FINDINGS}

On September 7, we visited ill children showing acute symptoms at their own home and collected throat washings from 11 among them and acute stage sera from 6 cases. An eye swab was also taken from a patient (H. Iwamatsu) who exhibited follicular conjunctivitis. On September 17 again, throat washings and an eye swab were collected from other 9 children at their acute stage. The results of laboratory examinations are summarized in Table 4.

Among the total 20 patients, four were reported to have eye involvement, but only two of them were having conjunctivitis at the time of our visits. Adenovirus. type 3 was isolated from the eye swabs of these two patients. The same virus was isolated also from 9 patients among them as shown in Table 4 . Both of those who were proved to contain the virus in their eye swabs, were evidenced to have the virus also in their throat washings. The other two patients, whose eye swabs were not examined though showing eye symptoms, were also proved to be positive for virus isolation from throat washings. The strains of adenovirus isolated in this epidemic were all typed as type 3.

Six pairs of sera of 6 patients among them, collected at acute and convalescent stages were all found to show antibody rises at the convalescent stage by both neutralization reaction against adenovirus type 3 and complement fixation reaction against adenovirus (Table 4). All of these six patients had a neutralization antibody titer of less than 1:2 and a complement fixation titer of less than $1: 4$ at the acute stage of illness. Virus isolation was not successful in two among these six serologically positive patients.

The throat washings of the 20 patients were also inoculated into embryonated eggs to test whether they contained any type of influenza viruses or not, but the 
results turned out to be negative. Further, the 5 pairs of the patients also showed no antibody rise in hemagglutination inhibition reaction against any of the previous $A$ type, the $B$ type or the A/Asia/57 type viruses (Table 5). These laboratory results seem to indicate that the present epidemic of adenovirus type 3 did not include influenza infections of any type as mixed infections in spite of the anticipation made at first that it might be a first sign of the second wave of the Asiatic flue. In addition, it should be noticed that all of the acute sera

Table 4. Results of virus isolation and serological reaction of the patients examined

\begin{tabular}{|c|c|c|c|c|c|c|c|c|c|}
\hline \multirow{3}{*}{$\begin{array}{l}\text { Case } \\
\text { No. }\end{array}$} & \multirow{3}{*}{ Names of cases } & \multirow{3}{*}{$\begin{array}{c}\text { Conjunc- } \\
\text { tivitis }\end{array}$} & \multirow{2}{*}{\multicolumn{2}{|c|}{$\begin{array}{l}\text { Virus } \\
\text { isolation }\end{array}$}} & \multirow{3}{*}{$\begin{array}{l}\text { Virus } \\
\text { type }\end{array}$} & \multicolumn{4}{|c|}{ Serum antibodies against adenovirus } \\
\hline & & & & & & \multicolumn{2}{|c|}{$\begin{array}{c}\text { Neutralization } \\
\text { against type } 3 \text { virus }\end{array}$} & \multicolumn{2}{|c|}{ Complement fixation } \\
\hline & & & throat & eye & & acute & convalescent & acute & convalescent \\
\hline 76 & & + & + & + & 3 & $<1: 2$ & $1: 128$ & $<1: 4$ & $1: 8$ \\
\hline 77 & & + & + & N.D. & 3 & & & & \\
\hline 78 & & - & + & N. D. & 3 & $<1: 2$ & $1: 32$ & $<1: 4$ & $1: 16$ \\
\hline 79 & & + & + & N. D. & 3 & & & & \\
\hline 80 & & - & + & N. D. & 3 & $<1: 2$ & $1: 32$ & $<1: 4$ & $1: 8$ \\
\hline 81 & & - & - & N. D. & & $<1: 2$ & $1: 16$ & $<1: 4$ & $1: 8$ \\
\hline 82 & & - & + & N. D. & 3 & & & & \\
\hline 84 & & - & + & N. D. & 3 & $<1: 2$ & $1: 8$ & $<1: 4$ & $1: 16$ \\
\hline 85 & & - & - & N. D. & & $<1: 2$ & $1: 64$ & $<1: 4$ & $1: 16$ \\
\hline 86 & & - & - & N. D. & & & & & \\
\hline 87 & & - & - & N. D. & & & & & \\
\hline 100 & & + & + & + & 3 & & & & \\
\hline 102 & & - & - & N. D. & & & & & \\
\hline 103 & & - & - & N. D. & & & & & \\
\hline 104 & & 一 & + & N. D. & 3 & & & & \\
\hline 105 & & 一 & - & \#N. D. & & & & & \\
\hline 106 & & - & 一 & N. D. & & & & & \\
\hline 107 & & - & - & N. D. & & & & & \\
\hline 108 & & - & - & N. D. & & & & & \\
\hline 109 & & - & - & N. D. & & & & & \\
\hline
\end{tabular}

\# Herpes virus was isolated from the throat of this patient

of the five patients had a considerable amount of antibodies against A/Asia/57 type virus, and this fact points out that they experienced an infection of this virus in the first wave of the Asiatic flue. Indeed, the school in question was stated to have a considerable number of cases and to be closed for several days during the period of the first Asiatic flue wave, and this is why discussions were provoked about the reinfections of $\mathrm{A} / \mathrm{Asia} / 57$ type virus at the time of the present epidemic.

The patient No. 76 ( $\square$ (Table 4), 9 years of age, exhibited his first symptoms on September 6. During his summer vacation, he swam at the sea for 3 days and in a river for 10 days, but otherwise almost every day at 
the Shihongi swimming pool. His illness was a typical form of pharyngoconjunctival fever. His younger sister, 7 years of age, was reported to consult a doctor because of having conjunctivitis at about the same period as his brother (the exact date was not remembered by her family). Because at that time she had neither fever nor other remarkable symptoms, it is not certain whether her conjunctivitis had some connection or not, but anyway her illness was reported to belong to the group $\mathrm{C}$ presented by the white column in Fig. 1 .

The patients No. 77 , 12 years old) and No. 78 years old) were brothers to each other and belonged to one and the same family. Both of them had the onset of their illness on the same day, namely on September 6. The patient No. 78 was attending the Oji Second Elementary School, while the patient No. 77 was a student in a middle school, namely the Oji First Middle School. The latter had conjunctivitis, while the former did not. They were both using mostly the Nanushinotaki pool for swimming. They had other two sisters,

Table 5. Hemagglutination-inhibition titers against influenza viruses of the acute and convalescent sera of the patients examined

\begin{tabular}{|c|c|c|c|c|c|c|c|}
\hline \multirow{3}{*}{$\begin{array}{l}\text { Case } \\
\text { No. }\end{array}$} & \multirow{3}{*}{ Name } & \multicolumn{6}{|c|}{ Serum antibodies against } \\
\hline & & \multicolumn{2}{|c|}{ A/Kojiya/1/52 } & \multicolumn{2}{|c|}{ B/Hamadayama/1/55 } & \multicolumn{2}{|c|}{ A/Adachi $/ 2 / 57$} \\
\hline & & acute & convalescent & acute & convalescent & acute & convalescent \\
\hline 76 & & $1: 64$ & $1: 128$ & $1: 16$ & $1: 16$ & $1: 128$ & $1: 128$ \\
\hline 78 & & $1: 64$ & $1: 128$ & $1: 32$ & $1: 32$ & $1: 128$ & $1: 128$ \\
\hline 81 & & $1: 64$ & $1: 128$ & $1: 8$ & $<1: 8$ & $1: 64$ & $1: 128$ \\
\hline 84 & & $1: 1024$ & $1: 1024$ & $1: 128$ & $1: 128$ & $1: 128$ & $1: 256$ \\
\hline 85 & & $1: 256$ & $1: 512$ & $1: 64$ & $1: 64$ & $1: 256$ & $1: 256$ \\
\hline
\end{tabular}

both of whom had cold symptoms such as sore throat, headache and a fever of about $39^{\circ} \mathrm{C}$ on August 31 and September 2, respectively. It was not clarified whether the transmission of the illness among the cases took place intra- or extrafamilially.

The patients No. 80 ( 8 years old), No. 81 ( 11 years old) and No. 82 ( 5 years old) were also cases of household occurrence. The patient No. 80 showed his first symptoms on September 2, while both of the others on September 5, namely 3 days later than the former. They were using the Shihongi swimming pool, until about the middle of August according to their statement, except for the patient No. 82, who was too young to go to the swimming pool.

The patient No. 104 ( 7 years old) started to get ill on September 14. His illness was confirmed to be adenovirus infection by virus isolation as shown in Table 4, but he did not go to swim at all. He had two sisters, one of them (9 years old) got ill on August 24, and the other (12 years old) on August 26. Both of them swam in the Shihongi pool almost every day until August 23.

The patients No. 105-109 belonged to one and the same family. The patient No. 106 was the mother of the others. The date of the onset, and the body 
Table 6. Illnesses of the members of the Takeda family

\begin{tabular}{|c|c|c|c|c|c|c|}
\hline $\begin{array}{l}\text { Case } \\
\text { No. }\end{array}$ & Name & Age & Sex & $\begin{array}{l}\text { Date of onset } \\
\text { of illness }\end{array}$ & $\begin{array}{c}\text { Maximal } \\
\text { temperature }\end{array}$ & $\begin{array}{c}\text { Herpes virus } \\
\text { isolation }\end{array}$ \\
\hline 105 & & 5 & female & September 10 & $39.5^{\circ} \mathrm{C}$ & + \\
\hline 106 & & 39 & female & September 12 & $39.8^{\circ} \mathrm{C}$ & - \\
\hline 107 & & 9 & male & September 10 & $40.2^{\circ} \mathrm{C}$ & - \\
\hline 108 & & 17 & female & September 15 & $39.3^{\circ} \mathrm{C}$ & - \\
\hline 109 & & 13 & male & September 12 & $39.7^{\circ} \mathrm{C}$ & - \\
\hline
\end{tabular}

temperature at that time is summarized in Table 6. As their illnesses seemed to be all quite typical for those of $B$ group, it is very likely that this was an example of intrafamilial occurrence of the disease in the epidemic in question. But isolation of adenovirus from these patients failed. On the contrary, a virus strain cytopathogenic for HeLa cells was isolated from the patient No. 105. This virus caused death in mice by intracerebral inoculation though it did not produce typical pocks on chorioallantoic membrane of embryonated eggs in the primary inoculation from HeLa cell materials. This virus was neutralized by the serum against herpes simplex virus (supplied by Dr. K. Yoshino in National Institute of Health, Tokyo). From these results it is proved to be the virus of herpes simplex. As already pointed out (Scott, 1957), that, the herpes simplex virus is isolated from persons of 3 to 14 years of age in 9 per cent, it is not unlikely that a ehild like the patient No. 105 ( 5 years old) happened to harbour this virus in her throat, even if her illness at that time was not due to it.

\section{Clinical Features}

It has already been mentioned above that the patients involved in the epidemic are divided into three groups, A, B, and C. The frequency distribution

Table 7. Frequency distribution of various symptoms in each group of the disease

\begin{tabular}{lrrrrr}
\hline \multirow{2}{*}{ Symptoms } & \multicolumn{3}{c}{ Classification of the illness } & \multirow{2}{*}{ Total } & \multirow{2}{*}{ Percentage } \\
\cline { 2 - 4 } & Group & A & Group B & Group C & \\
Fever & 30 & 242 & & 272 & $79 \%$ \\
Headache & 18 & 154 & 22 & 194 & $57 \%$ \\
Sore throat & 17 & 116 & 27 & 161 & $47 \%$ \\
Cough & 5 & 38 & 36 & 79 & $23 \%$ \\
Conjunctival injection & 25 & 53 & 18 & 96 & $28 \%$ \\
Eye puss & 30 & & 2 & 32 & $9 \%$ \\
Abdominal pain & 3 & 29 & 6 & 38 & $11 \%$ \\
Diarrhea & 9 & 35 & 1 & 45 & $13 \%$ \\
Skin rash & 2 & 5 & 1 & 8 & $2 \%$ \\
\hline Total number of cases & 30 & 242 & 71 & 343 & \\
\hline
\end{tabular}


of various symptoms in each of these groups is summarized in Table 7 from the data of 343 patients reported in the epidemic. As a whole, only $30(8.7 \%)$ showed the typical symptoms of pharyngoconjunctival fever among total 343 cases. However, the percentage of those who showed conjunctivitis is supposed to be more or less higher than that reported, because it is likely that some of them happened not to report their conjunctival symptoms in response to our questionaires. In fact, two patients who had showed remarkable conjunctival involvement at the time of their illness, did not report their eye symptoms and as the result they were classified to belong to the group B.

Among 71 cases in the group C, 2 were reported to have had eye secretions. Generally speaking, some people do not usually estimate their body temperature during their illness if it is not so high, and in such cases they may happen to report that they have had no fever. Thus, it is more or less probable that some of those reported to belong to the group $\mathrm{C}$ may have had fever. Therefore, it is quite likely that some cases of the group $\mathrm{C}$ was suffering from adenovirus infection with more or less fever.

Next, the correlation of a kind of rash and adenovirus infection must be mentioned here. As shown in Table 7, answers to our questionaires indicate that there were some cases who showed rashes during the course of their illness. When we visited the school for the second time, we were able to observe two such cases by ourselves who had developed skin rash. The case reports of them are as follows.

Case 1. 8 years old, male (patient No.79 in Table 4).-His illness started on September 6, 1957, with a fever of $39.1^{\circ} \mathrm{C}$, a chill, and coughs. A little later from the onset of his illness, he developed bilateral conjunctivitis and furthermore 3 days after the onset, he had skin rash. This rash had already disappeared when we examined him, but according to his talk, it was maculopapular appearance just like urticaria and was localized mainly on the abdominal side of the trunk. The rash disappeared about 3 days later, leaving faint pigmentation. Type 3 adenovirus was isolated from his throat washing. His disease was at first diagnosed as Izumi fever* by a doctor because of his skin rash.

Case 2. 8 years old, female.-She began to be sick on August 30,1957 , with a fever of $38.5^{\circ} \mathrm{C}$. On September 5, rash developed mostly on the abdominal side of the trunk, the flexion side of the upper extremities, and the inner side of the thighs. The rash happened to be observed by one of us (J.N.) who recognized it just similar to that of scarlet fever. It disappeared several days later, leaving some desquamation and pigmentation. A little earlier than the appearance of the rash, conjunctivitis developed, first at the right eye and then at the other. Swelling of submandibular lymph nodes was palpable. This case had been also diagnosed as Izumi fever* by the same doctor.

* The Izumi fever is a disease with a typical skin rash which has long been recognized in Japan first by Dr. S. Izumi in Kanazawa University as a disease entity probably due to a viral agent. 


\section{Discussion}

Nakano and Akiyama (1957) reported an outbreak of a febrile disease which had occurred among school children in an elementary school at Fuji City, Shizuoka Prefecture in the summer of 1955, and was supposed to be spread through swimming in a swimming pool. They described clinical features of the disease in detail, but could not identify it as any of the known disease though some mention was made to adenovirus infections.

In the next year (1956), Dr. Y. Kokubu in Tokyo Jikeikai Medical College reported to us that a number of cases of a similar disease had been occurring among school children in an elementary school in Tokyo, and the spread of the disease seemed to be due to swimming pool contamination. According to Dr. Kokubu's report, 3 among the total 16 cases examined by him showed typical pharyngoconjunctival fever. Blood samples were taken at both acute and convalescent stages from 4 cases and only convalescent blood samples were taken from remaining 12 cases. The results of examination of these sera were somewhat disappointing, because no evidence was obtained of antibody rise at a convalescent stage by complement fixation reaction with adenovirus. However, a relatively large number of cases among them had a fairly high titer of complement fixation antibody against adenovirus. Among the 4 cases from whom both acute and convalescent blood samples were taken, three cases had an antibody titer of $1: 8$ to $1: 32$ in the both of their paired blood samples. The conclusion is somewhat obscured by the fact that the acute blood samples were taken a little too late.

Being suggested by the above experiences at any rate, we were thinking that there might be sometimes outbreaks of adenovirus infections that were spread through swimming in a pool in the summer time, and expecting to study such cases in detail. The outbreak of adenovirus infections at the Oji Second Elementary School, which has been described in the present paper, happened to occur at such a time. As has been described above, it is not certain whether or not the epidemic was due to swimming pool contamination, or in what extent if it was the case. However, it may be thought that there is some degree of possibility in incrimination of the swimming pools, because of the absence of remarkable case-accumulation either in certain school classes or in certain residence districts. It is, of course, not excluded, that some of the cases were spread and transmitted through contact in a class room or in a household.

Next, considerations were already made in our previous publications (Fukumi, Nishikawa, Kokubu and Nakayama, 1957; Fukumi, Nishikawa, Nakamura, Watanabe, Kitayama, and Kinoshita, 1957), about the skin rash due to adenovirus infections, and the present experience seems to confirm our previous insistance further. It is somewhat interesting in this viewpoint to mention here that there was a case among those mentioned above as the cases reported to us by Dr. 
Kokubu, who showed conjunctivitis with rash similar to that of scarlet fever, and furthermore, that a case with rash like urticaria was included among the cases described by Nakano and Akiyama (1957).

\section{SUMMARY}

An epidemic of adenovirus type 3 infections in an elementary school is here reported, and some discussions are made about the modes of the spread of infections, especially taking into consideration the possibility of the spread due to swimming pool contamination.

A discussion is also made about the relation between a kind of skin rash and adenovirus infections, describing two such cases in detail.

\section{REFERENCES}

Bell, J. A., Rowe, W. P., Engler, J. I., Parrott, R. H., \& Huebner, R. J. (1955) : Pharyngoconjunctival fever: Epidemiological studies of a recently recognized disease entity. J. A. M. A., 157, 1083-1092.

Fukumi, H., Mizutani, H., Nishikawa, F., Yamamoto, M., Okuma, M., \& Kuriyama, S. (1958): Epidemiological and clinical studies of A/Asia/1957 type influenza in a nursery near Tokyo City. Jap. J. M. Sc. \& Biol., 11, 1-12.

Fukumi, H., Nishikawa, F., Kokubu, Y., \& Nakayama, T. (1957): Isolation of adenovirus from an exanthematous infection resembling roseola infantum. Jap. J. M. Sc. \&. Biol., 10, 87-91.

Fukumi, H., Nishikawa, F., Nakamura, K., Watanabe, T., Kitayama, T., \& Fujita, C. (1957): Studies on the adenovirus as an etiological agent of pharyngoconjunctival fever. Jap. J. M. Sc. \& Biol., 10, 79-85.

Fukumi, H., Nishikawa, F., Nakamura, K., Watanabe, T., Kitayama, T., \& KinoSHITA, T. (1957): Further studies of the cases associated with adenoviruses. Jap. J. M. Sc. \& Biol., 10, 407-418.

NAKANo, H., \& AkiYama, Y. (1957): An outbreak of a febrile disease among school children. "Internal Medicine and Pediatrics", 12, 693-695 (text in Japanese).

Scotт, T. F. M. (1957): Epidemiology of herpetic infections. Am. J. Ophth., 43, (Number 4, Part II), 134-147. 